Research Paper

\title{
A transcriptional complex composed of ER(a), GATA3, FOXA1 and ELL3 regulates IL-20 expression in breast cancer cells
}

\author{
Jae Yong Lee ${ }^{1}$, Young Joon Park ${ }^{1}$, Nuri Oh ${ }^{1}$, Kyu Bum Kwack ${ }^{1}$ and Kyung-Soon Park ${ }^{1}$ \\ ${ }^{1}$ Department of Biomedical Science, College of Life Science, CHA University, Seoul, Korea \\ Correspondence to: Kyung-Soon Park, email: kspark@cha.ac.kr \\ Keywords: estrogen receptor alpha, GATA3, FOXA1, ELL3, interleukin-20 \\ Received: September 08, $2016 \quad$ Accepted: April 15, $2017 \quad$ Published: April 27, 2017 \\ Copyright: Lee et al. This is an open-access article distributed under the terms of the Creative Commons Attribution License 3.0 (CC BY 3.0), \\ which permits unrestricted use, distribution, and reproduction in any medium, provided the original author and source are credited.
}

\section{ABSTRACT}

Interleukin-20 (IL-20) is a member of the IL-10 family. IL-20 expression is regulated by a transcription elongation factor, EII3, in estrogen receptor-positive $(\operatorname{ER}(+))$ breast cancer cells. In this study, we demonstrated that ER(a), GATA3 and FOXA1 form a transcriptional complex with Ell3 to regulate IL-20 expression in ER(+) breast cancer cells. We also determined that GATA3 and FOXA1 share a binding site with $\operatorname{ER}(a)$ in the interleukin-20 promoter. Furthermore, we found that FOXA1 represses IL-20 expression, whereas GATA3 and ER(a) activate it. In addition, we demonstrated that EII 3 associates with ER(a) to increase its binding affinity to the IL-20 promoter, which may prevent FOXA1 binding to the same region of this promoter. Our results expand upon the current understanding of the regulatory mechanism of $I L-20$ in cancer.

\section{INTRODUCTION}

Estrogen receptor alpha $\operatorname{ER}(\alpha)$ is a critical nuclear hormone receptor that regulates breast epithelial cell proliferation and apoptosis. It also contributes to the malignancy of breast cells, and approximately $75 \%$ of breast cancers have been reported to be estrogen receptor positive $\mathrm{ER}(+)$. Therefore, the ER signaling pathway has been studied as a therapeutic target in breast cancer therapy. ER(+) breast cancer patients are typically treated with endocrinebased therapy; however, resistance to endocrine-based drugs is an emerging challenge. Endocrine therapy resistance is considered to result from the complex crosstalk between estrogen signaling and other oncogenic signaling pathways. In response to estrogen, $\mathrm{ER}(\alpha)$ coordinates with coactivators and corepressors to induce a physiological response, and deregulation of coregulatory mechanisms is associated with the development and metastasis of breast cancer $[1,2]$.

Thus, a thorough understanding of the coordinating partners and transcriptional target genes of $\operatorname{ER}(\alpha)$ is critical to identify novel therapeutic targets and to overcome endocrine therapy resistance in breast cancer.

Ell3 was originally identified as a testis-specific transcription elongation factor belonging to the elevennineteen lysine-rich leukemia (Ell) family, but its nucleotide sequence is divergent from those of Ell1 and
El12 [3]. In mouse embryonic stem cells (mESCs), Ell3 associates with enhancers and mediates the occupancy of RNA Pol II at the promoter-proximal regions of development-related genes to prime subsequent gene activation following differentiation signals by recruiting the super elongation complex to these loci [4]. In addition, Ell3 promotes p53 degradation in mESCs, which contributes to the protection of differentiating cells [5]. We recently reported that ectopic expression of Ell3 stabilizes p53 in an ER $(+)$ breast cancer cell line by activating the expression of interleukin $20(I L-20)$, leading to chemosensitization of MCF7 cells upon CDDP treatment [6].

$I L-20$ is a pleiotropic cytokine that is associated with inflammatory diseases, such as rheumatoid arthritis and atherosclerosis [7]. Recently, several studies have demonstrated that $I L-20$ plays a critical role in tumor progression. $I L-20$ promotes the migration and invasion of bladder cancer cells by activating ERK pathwaymediated MMP-9 protein expression [8]. Furthermore, IL-20 activates STAT3 and ERK signaling in oral cancer cells to increase cell proliferation and colony formation [9]. $I L-20$ expression is induced by direct binding of the NF-kB p50/p65 heterodimer in human keratinocytes [10]. Although $I L-20$ is assumed to be a key cytokine in the pathogenesis of cancer, little is known about the factors involved in its regulation in cancer. 
In this study, we show that Ell3, ER( $\alpha)$, GATA3 and FOXA1 form a transcriptional complex to regulate $I L-20$ expression in $\mathrm{ER}(+)$ breast cancer cell lines. We further demonstrate that Ell3 associates with ER $\alpha$ and GATA3 to enhance binding affinity to the $I L-20$ promoter. We also show that FOXA1 functions as a transcriptional repressor of $I L-20$ by interfering with binding of $\operatorname{ER}(\alpha)$ and GATA3 to the $I L-20$ promoter.

\section{RESULTS}

\section{$\mathrm{ER}(\alpha)$ regulates IL-20 expression in breast cancer cells}

In a previous study, we reported that transcription elongation factor E113 directly regulates $I L-20$ expression in an $\mathrm{ER}(+)$ breast cancer cell line, MCF7, but not in $\mathrm{ER}(-)$ breast cancer cell lines [6]. Based on these results, we hypothesized that $\operatorname{ER}(\alpha)$ is a transcriptional activator of $I L-20$ expression in MCF7 cells.

As a first step in evaluating whether $\operatorname{ER}(\alpha)$ activity is associated with $I L-20$ expression, we examined the effect of estrogen on $I L-20$ expression in $\mathrm{ER}(+)$ MCF7 cells and ER(-) MDA-MB-231 cells. Because $\operatorname{ER}(\alpha)$ is translocated into the nucleus to function as a transcriptional activator following estrogen treatment, we hypothesized that $I L-20$ expression in $\mathrm{ER}(+)$ cells would be enhanced by estrogen if its expression is regulated by $\operatorname{ER}(\alpha)$. As expected, the $I L-20$ RNA and secreted protein levels were significantly increased by estrogen in MCF7 cells but did not change in MDA-MB-231 cells (Figure 1A). To examine the effect of ER depletion on IL-20 expression in MCF7 cells following estrogen treatment, we first tested the suppression efficiency of siRNA targeting $\operatorname{ER}(\alpha)$. As shown in Figure $1 \mathrm{~B}$, $100 \mathrm{nM}$ siRNA decreased ER( $\alpha$ ) expression by up to $70 \%$ at both the RNA and protein levels. Following transfection of MCF7 cells with $25 \mathrm{nM}, 50 \mathrm{nM}$ or $100 \mathrm{nM} \operatorname{siER}(\alpha)$, the amount of secreted $I L-20$ decreased in proportion to the concentration of siRNA targeting ER( $\alpha$ ) (Figure 1C). Furthermore, depletion of $\operatorname{ER}(\alpha)$ by siRNA impeded the effect of estrogen on enhancing $I L-20$ expression (Figure 1D). These results indicate that $\operatorname{ER}(\alpha)$ functions to activate $I L-20$ transcription in $\operatorname{ER}(+)$ MCF7 cells. To our surprise, the ectopic expression of $\operatorname{ER}(\alpha)$ in MDA-MB-231 cells enhanced the expression of $I L-20$ at both the RNA and protein levels by approximately $\sim 2$-fold in the presence or absence of estrogen, indicating that $\operatorname{ER}(\alpha)$ activated $I L-20$ expression in the triple negative breast cancer cell line (Figure 1E). Consistent with the results for MCF7 cells, $I L-20$ expression in another $\mathrm{ER}(+)$ breast cancer cell line, T47D, was also enhanced by estrogen treatment and suppressed by the depletion of $\operatorname{ER}(\alpha)$ (Supplementary Figure 2A-2C).

\section{$\operatorname{ER}(\alpha)$ collaborates with Ell3 to regulate IL20 expression}

To determine whether the Ell3-mediated enhancement of $I L-20$ transcriptional expression is associated with $\operatorname{ER}(\alpha)$, we examined the effect of estrogen on $I L-20$ expression in Ell3 OE cells. $I L-20$ expression was enhanced by El13 overexpression and was further increased by estrogen treatment (Figure 2A). Depletion of $\operatorname{ER}(\alpha)$ resulted in a decrease in $I L-20$ expression in Ell3 OE cells and in the control MCF7 cells (Figure 2B). Furthermore, the effect of estrogen on enhancing $I L-20$ expression was impeded by $\operatorname{siER}(\alpha)$ in Ell3 OE cells (Figure 2C). Following suppression of Ell3 by siRNA in MCF7 cells, $I L-20$ expression was decreased, and the effect of estrogen on enhancing $I L-20$ expression was inhibited (Figure 2D). Similar to the results for MCF7 cells, the suppression of Ell3 resulted in a decrease in $I L-20$ expression in both the presence and absence of estrogen (Supplementary Figure 2D-2E). Cotransfection of $\operatorname{siER}(\alpha)$ and siEll3 into MCF7 cells had an additive effect on suppressing $I L-20$ expression compared with the transfection of $\operatorname{siER}(\alpha)$ or siEll3 alone (Figure 2E). We next performed a co-immunoprecipitation experiment to determine whether the transcription elongation factor El13 directly associates with the transcription factor $\operatorname{ER}(\alpha)$ to regulate $I L-20$ expression. Following immunoprecipitation of total cell extracts of MCF7 cells with an anti-ER $(\alpha)$ or anti-Ell3 antibody, $\operatorname{ER}(\alpha)$ or Ell3 was co-immunoprecipitated, respectively (Figure $2 \mathrm{~F}$ ). Taken together, these results demonstrate that Ell3 and $\operatorname{ER}(\alpha)$ form a transcriptional complex to activate $I L-20$ expression.

\section{ER( $\alpha$ ) directly binds to the IL-20 and Ell3 promoters to regulate their gene expression}

We next assessed whether $\operatorname{ER}(\alpha)$ directly binds to the $I L-20$ promoter by chromatin immunoprecipitation $(\mathrm{ChIP})$ analysis. We scanned the promoter region $(<1 \mathrm{~kb})$ of human $I L-20$ using a genome browser based on the ER $(\alpha)$ Chromatin Interaction Analysis with Paired-End Tag Sequencing (ChIA-PET) signal and then divided the $I L-20$ promoter into four regions, R1 to R4 (Figure 3A, Left panel). We next performed ChIP analysis of MCF7 cells using an anti-ER $(\alpha)$ antibody. Normal rabbit IgG was used as a negative control, and anti-acetylated histone $\mathrm{H} 3(\mathrm{AcH} 3)$ was used as a positive control. PCR amplification revealed that the amount of immunoprecipitated R1 and R2 was increased by at least three-fold in Ell3 OE cells compared with that in the control MCF7 cells (Figure 3A, Right panel). To further assess whether $\operatorname{ER}(\alpha)$ directly regulates the activity of the $I L-20$ promoter, we next performed a luciferase activity assay with the $I L-20$ promoter. As shown in Figure 3B, cotransfection of $\operatorname{ER}(\alpha)$ with a luciferase reporter plasmid 
carrying the $I L-20$ promoter increased the luciferase activity up to 3-fold, and the addition of Ell3 further increased the luciferase activity. To mutate the $\operatorname{ER}(\alpha)$ binding site of the $I L-20$ promoter, we scanned the estrogen response element sequences (ERE: 5'-AGGTCANNNTGACCT-3') in the $I L-20$ promoter (Supplementary Figure 1A). We identified two ERE half sites from -92 to -97 and -788 to -793 in the $I L-20$ promoter (Supplementary Figure $1 \mathrm{~B}$ ). We mutated two of the ERE half sites of $I L-20$ and then compared their luciferase activity with that of wild type upon $\operatorname{ER}(\alpha)$ expression. As expected, $\operatorname{ER}(\alpha)$-mediated activation of the $I L-20$ promoter with a point mutation at the ER half site was significantly lower than that of the wild type promoter (Figure 3C). When both of the ERE half sites in the $I L-20$ promoter were mutated, the promoter activity was even lower than that of the promoter with a single mutation (Figure 3C). These results indicated that $\operatorname{ER}(\alpha)$ is a transcriptional activator of the $I L-20$ promoter. Since transfection of $\operatorname{siER}(\alpha)$ into MCF7 cells resulted in the suppression of Ell3 protein and $\operatorname{ER}(\alpha)$ protein levels (Figure 1B), we next examined whether $\operatorname{ER}(\alpha)$ also regulates the transcription of Ell3. As expected, the siRNA-mediated suppression of $\operatorname{ER}(\alpha)$ resulted in a decrease in the Ell3 transcript level (Figure 3D). To determine whether $\mathrm{ER}(\alpha)$ directly regulates Ell3 expression, we scanned the Ell3 promoter $(<1 \mathrm{~kb})$ and identified three EREs upstream of the Ell3 transcriptional start site (Figure 3E, left panel). We conducted ChIP assays to assess the binding of $\operatorname{ER}(\alpha)$ to this potential binding site in the Ell3 promoter and confirmed that $\operatorname{ER}(\alpha)$ bound to the $\mathrm{R} 1$ region of this promoter (Figure 3E, Right panel). Based on these results, we concluded that $\operatorname{ER}(\alpha)$ activates the transcription of $I L-20$ and Ell3, possibly by direct binding to the promoter of each gene.

\section{$\operatorname{ER}(\alpha)$, GATA3 and FOXA1 collectively regulate IL-20 expression}

GATA3 and FOXA1 are considered ER-related genes because they are co-expressed with $\operatorname{ER}(\alpha)$ in breast tumors and in breast cancer cell lines [11]. In addition, these triple factors are components of an enhanceosome that functions in combinatorial control of the transcriptional network in $\mathrm{ER}(+)$ breast cancer cells [12].

Our results suggest that $\operatorname{ER}(\alpha)$ is a transcriptional activator of $I L-20$; thus, we next evaluated whether GATA3 and FOXA1 are also related to $I L-20$ expression. First, we assessed whether GATA3 and FOXA1 form a complex with $\operatorname{ER}(\alpha)$ and Ell3. As expected, $\operatorname{ER}(\alpha)$, GATA 3 and FOXA1 co-immunoprecipitated with each other, indicating that these three proteins form a complex, at least in MCF7 cells (Figure 4A). Notably, Ell3 was associated with GATA3 but not with FOXA1 (Figure 4A).

We next examined whether GATA3 regulates $I L-20$ expression by assessing the effect of siGATA3 on $I L-20$ expression. As expected, GATA3 depletion resulted in the suppression of $I L-20$ in control and El13 OE cells in both the presence and absence of estrogen (Figure 4B). We next examined whether GATA3 regulates $I L-20$ expression
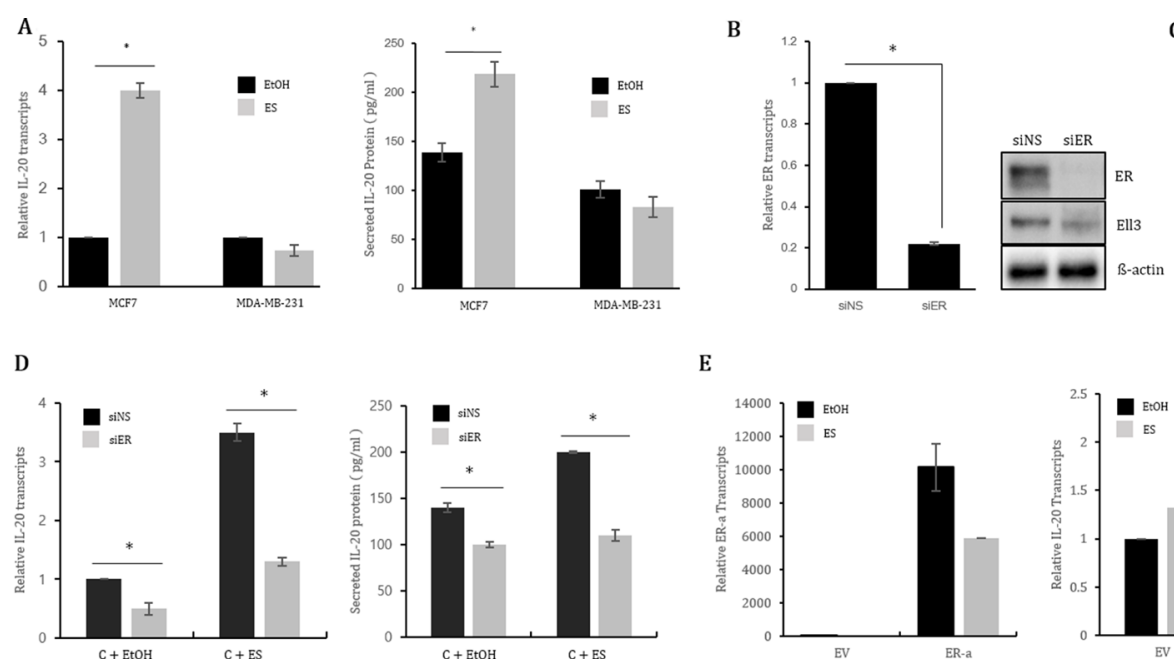
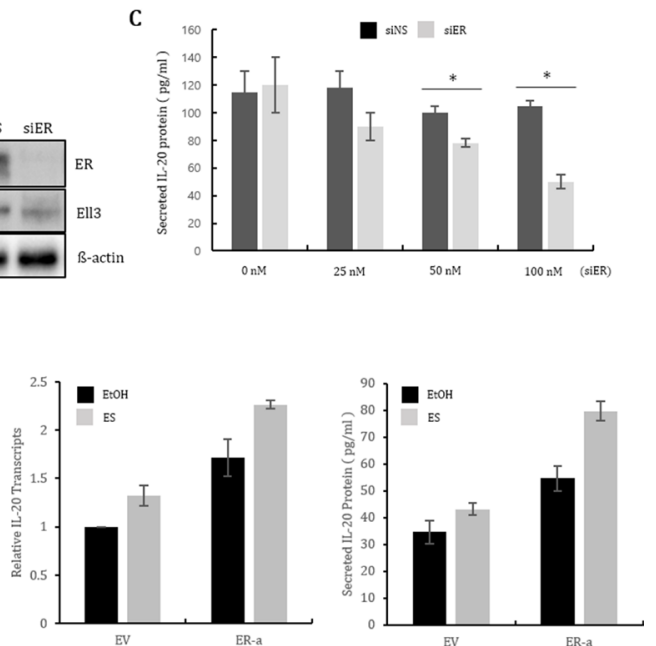

Figure 1: $\mathbf{E R}(\boldsymbol{\alpha})$ regulates $\boldsymbol{I L - 2 0}$ expression in MCF7 cells. (A) The effect of estrogen treatment on $I L-20$ expression. $I L-20$ expression following ES treatment was analyzed by real-time RT-PCR and ELISA in MCF7 and MDA-MB-231 cells treated with ES for $48 \mathrm{~h}$. (B) The suppression efficiency of siRNA targeting ER( $\alpha$ ) was analyzed by real-time RT-PCR and immunoblot assay in MCF7 cells transfected with $100 \mathrm{nM}$ of siRNA for $48 \mathrm{~h}$. (C) The effect of ER( $\alpha)$ suppression on $I L-20$ expression. The amount of secreted $I L-20$ protein was analyzed by ELISA for MCF7 cells transfected with the indicated concentrations of siRNA for $48 \mathrm{~h}$. (D) The effect of estrogen treatment on $I L-20$ expression in MCF7 cells transfected with siER $(\alpha)$. MCF7 cells were transfected with siNS or siER $(\alpha)$ for 24 h, followed by treatment with ES for $48 \mathrm{~h}$, and they were then analyzed by real-time RT-PCR and ELISA. (E) The effect of ER( $\alpha)$ overexpression on $I L-20$ expression in the presence or absence of ES. ER $(\alpha)$ transcript, $I L 20$ transcript and secreted $I L-20$ protein levels were analyzed in MCF7 cells transfected with a control (EV) or ER( $\alpha$ ) expression plasmid (ER- $\alpha)$ for $48 \mathrm{~h}$. Abbreviation: ES, estrogen $10 \mathrm{nM}$; EtOH $(0.1 \%)$, ethanol; siNS, non-specific siRNA; siER, siRNA targeting ER( $\alpha)$; ER, estrogen receptor alpha. The error bars represent the standard errors from three independent experiments, which were each performed using triplicate samples. ${ }^{*} P<0.05$ (Student's $t$-test). 
by direct binding to the $I L-20$ promoter. Because the results shown in Figure $4 \mathrm{~A}$ revealed that $\operatorname{ER}(\alpha)$ directly binds to GATA3, we hypothesized that the binding site of GATA3 overlaps with that of $\operatorname{ER}(\alpha)$ in the $I L-20$ promoter. To verify that GATA3 binds to these regions of the $I L-20$ promoter, we performed ChIP analysis of MCF7 cells using an anti-GATA3 antibody. PCR amplification revealed that the amount of the R2 region of the $I L-20$ promoter immunoprecipitated by the GATA3 antibody was increased by at least twentyfold compared to that immunoprecipitated by the IgG antibody (Figure 4C). In contrast to $\operatorname{ER}(\alpha)$, which exhibited increased binding affinity to the $I L-20$ promoter in Ell3 OE cells (Figure 3A), the binding of GATA3 to R2 was not enhanced in these cells, suggesting that Ell3 does not affect the binding affinity of GATA3 to the $I L-20$ promoter (Figure 4C). To this end, we further examined the effect of GATA3 depletion on the binding affinity of $\operatorname{ER}(\alpha)$ to this promoter. As shown in Figure 4D, the binding affinity of $\operatorname{ER}(\alpha)$ to the $I L-20$ promoter was not affected by the depletion of GATA3, despite the fact that GATA3 and $\operatorname{ER}(\alpha)$ form a transcriptional complex and bind to the same region of this promoter.

In contrast to GATA3, the siRNA-mediated depletion of FOXA1 resulted in an increase in $I L-20$ expression in both the presence and absence of estrogen, indicating that FOXA1 is a negative regulator of $I L-20$ (Figure 4E). Notably, FOXA1 expression was significantly decreased in the presence of estrogen, suggesting that estrogen regulates its transcription (Figure 4E). In ChIP analysis, the amounts of the R1 and R2 regions of the $I L-20$ promoter immunoprecipitated by the FOXA1 antibody were increased up to 10 -fold compared to that immunoprecipitated by the IgG antibody (Figure 4F). In addition, the amounts of the $\mathrm{R} 1$ and $\mathrm{R} 2$ regions immunoprecipitated by the FOXA1 antibody was significantly lower in Ell3 OE cells than in control cells (Figure 4F).

Luciferase activity assays further confirmed that GATA3 enhances the activity of the $I L-20$ promoter and that FOXA1 inhibits the enhancement of the activity of the $I L-20$ promoter by GATA3 (Figure 4G). Thus, we conclude that GATA3 is a positive regulator and that FOXA1 is a negative regulator of $I L-20$ in MCF7 cells.

\section{DISCUSSION}

$I L-20$ is a pleiotropic cytokine involved in cancer, atherosclerosis, rheumatoid arthritis, and stroke. $I L-20$ has recently been reported to play a pivotal role in
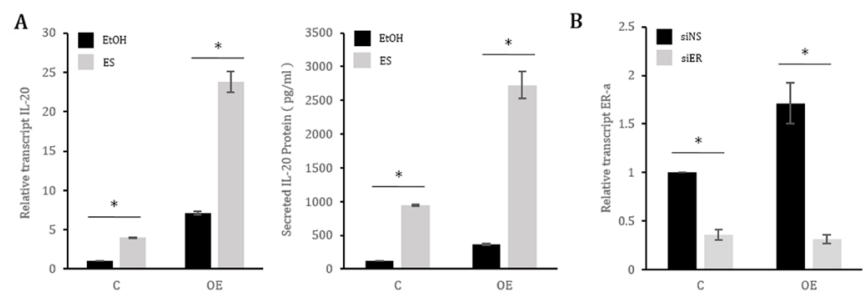

D

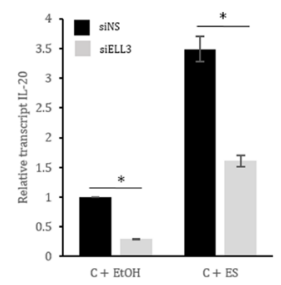

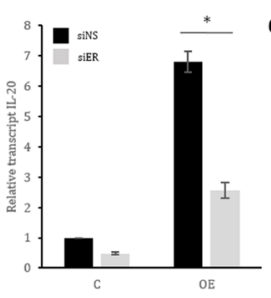

E

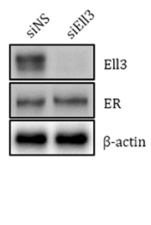

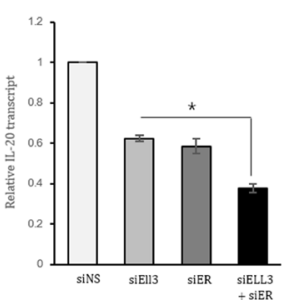
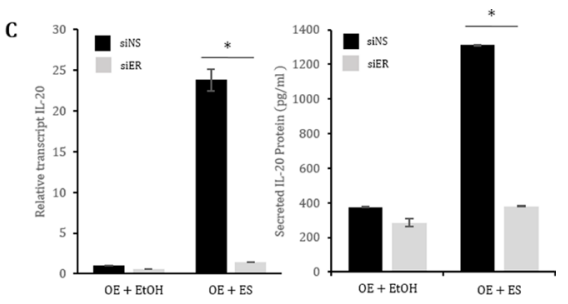

F
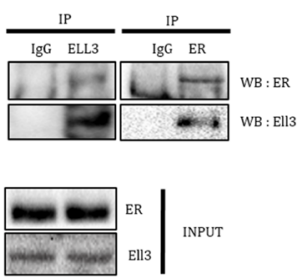

Figure 2: $\operatorname{ER}(\boldsymbol{\alpha})$ collaborates with Ell3 to regulate $\boldsymbol{I L - 2 0}$ expression in MCF7 cells. (A) The effect of estrogen treatment on $I L-20$ expression in El13-overexpressing MCF7 (Ell3 OE) cells. Control and Ell3 OE cells were treated with ES for 48 h, and then $I L-20$ expression was analyzed by real-time RT-PCR and ELISA. (B) The effect of ER( $\alpha$ ) suppression on $I L-20$ expression in Ell3 OE cells. Ell3 OE cells were transfected with siNS or $\operatorname{siER}(\alpha)$ for $48 \mathrm{~h}$, followed by analysis by real-time RT-PCR and ELISA. (C) The effect of ES treatment on $I L-20$ expression in ER( $\alpha$ )-suppressed Ell3 OE cells. El13 OE cells were transfected with siNS or siER( $\alpha)$ for 24 h, followed by treatment with ES for $24 \mathrm{~h}$ and analysis by real-time RT-PCR and ELISA. (D) The effect of ES treatment on $I L-20$ expression in Ell3suppressed MCF7 control cells. The suppression efficiency of siRNA targeting El13 was analyzed by immunoblot assay in MCF7 cells transfected with siRNA for $48 \mathrm{~h}$ (left panel). Control cells were transfected with siNS or siEll3 for $24 \mathrm{~h}$ and were then treated with ES for $24 \mathrm{~h}$, followed by analysis of $I L-20$ expression by real-time RT-PCR and ELISA (middle and right panels). (E) The effect of co-suppression of El13 and ER $(\alpha)$ on $I L-20$ expression in MCF7 cells. (F) Co-immunoprecipitation (IP) between ER( $\alpha$ ) and Ell3. MCF7 cell lysates were precipitated with anti-ER $(\alpha)$ or anti-Ell3 antibody-conjugated agarose and blotted with either an anti-El13 or anti-ER( $\alpha)$ antibody as indicated. Abbreviation: C, control MCF7 cells; OE, Ell3-overexpressing cells; ES, estrogen (10 nM); EtOH (0.1\%), ethanol; siNS, non-specific siRNA; siER, siRNA targeting ER $(\alpha)$; siEl13, siRNA targeting Ell3; ER, estrogen receptor $(\alpha)$; IP, immunoprecipitation; WB, western blot. The error bars represent the standard errors from three independent experiments, which were each performed using triplicate samples. ${ }^{*} P<0.05$ (Student's $t$-test). 
tumor progression, and its expression has been strongly associated with the clinical outcomes of breast cancer patients [13]. However, the transcriptional regulatory mechanism underlying adjustment of $I L-20$ levels in cells is largely unknown. In this study, we showed that expression of the pro-inflammatory cytokine $I L-20$ was regulated by a transcriptional complex composed of the transcription factors $\operatorname{ER}(\alpha)$, GATA3, and FOXA1 and the transcriptional elongation factor Ell3 in $\mathrm{ER}(+)$ breast cancer cells.

As summarized in Figure 5A, we determined that FOXA1 is a transcriptional repressor, whereas $\operatorname{ER}(\alpha)$ and GATA3 are transcriptional activators of $I L-20$ expression. Our results revealed that the binding sites of these three factors overlap in the $I L-20$ promoter. In addition, our results revealed the dynamics of the binding of $\operatorname{ER}(\alpha)$ and FOXA1 to this promoter, which was dependent on the concentration of Ell3. Although Ell3 did not bind to FOXA1, as demonstrated by co-immunoprecipitation analysis (Figure 4A), Ell3 overexpression had a negative effect on the binding affinity of FOXA1 to the $I L-20$ promoter. As FOXA1 and $\operatorname{ER}(\alpha)$ compete for binding to the same regions of this promoter (R1 and R2), FOXA1 might be precluded from binding to this promoter by $\mathrm{ER}(\alpha)$, the binding affinity of which was enhanced by Ell3. The fact that FOXA1 is a negative regulator of tumor promoting cytokine, $I L-20$, suggests that FOXA1 can be a useful prognostic marker for receptor-positive breast cancer.

Consistently, it was recently reported that FOXA1 expression is associated with a less aggressive phenotype and better prognosis in patients with hormone receptorpositive/HER2-negative breast cancer [14]. Because Ell3 is an additional factor to the triple complex of $\operatorname{ER}(\alpha)$, GATA3 and FOXA1 and this complex fine-tunes the expression level of $I L-20$, it will be essential to assess the clinical meaning of the expression of FOXA1 in combination with the expression of Ell3 in $\operatorname{ER}(\alpha)$ breast cancer patients.

Interestingly, ectopic expression of $\operatorname{ER}(\alpha)$ induced the expression of $I L-20$ in MDA-MB-231 cells. This finding suggests that the chromatin of the $I L-20$ promoter
A
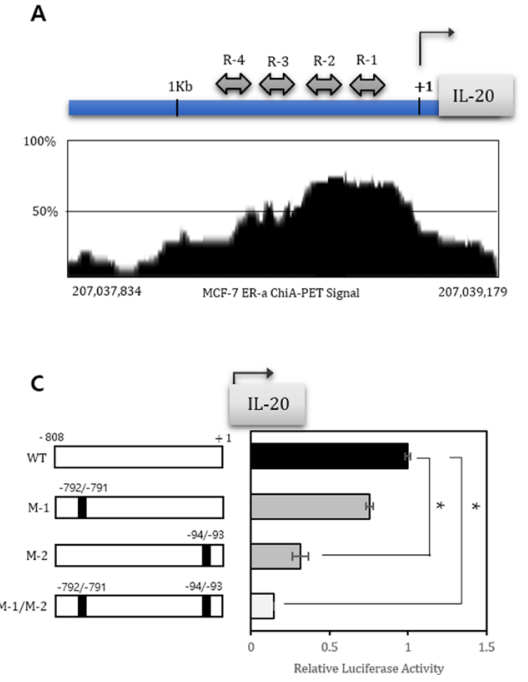

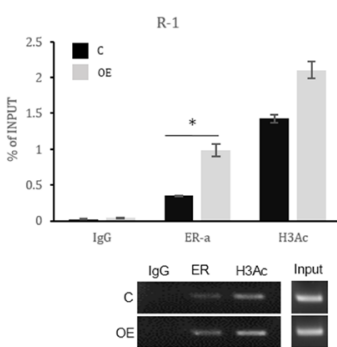

D

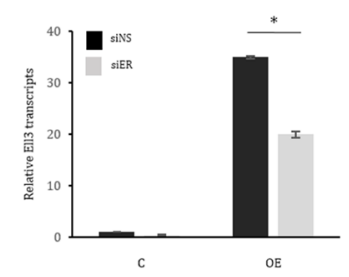

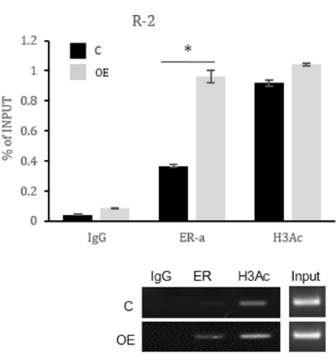

B

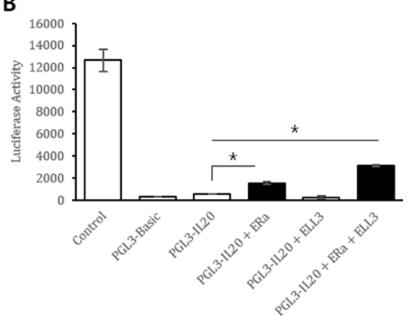

E

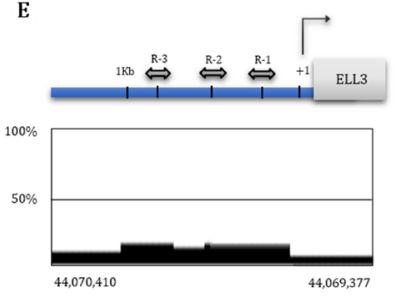

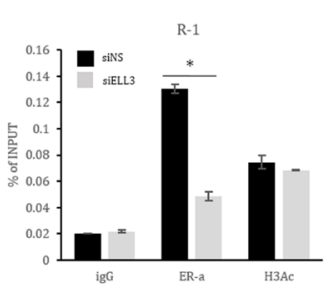

Figure 3: $\mathbf{E R}(\boldsymbol{\alpha})$ is a transcriptional activator of $\boldsymbol{I L - 2 0}$ and Ell3. (A) Left panel: Schematic diagram of the $I L-20$ promoter. The IL-20 promoter was divided into four regions based on the Paired-End Tag Sequencing (ChIA-PET) signal, named R1 to R4 (R1, chr 206,863,966 206,864,160; R2, chr 206,864,125 206,864,322; R3, chr 206,864,355 206,864,571; and R4, chr 206,864,727 206,864,950). Right panel: Chromatin from control and El13 OE cells was immunoprecipitated (ChIP) with antibodies against IgG, ER( $\alpha$ ) and H3Ac. The PCR results for R1 and R2 of the $I L-20$ promoter are presented. (B) Luciferase activity assay with the $I L-20$ promoter. $293 \mathrm{~T}$ cells were transfected with the indicated plasmid for $24 \mathrm{~h}$, and cell lysates were analyzed for luciferase activity. The positive control is the pGL3-control plasmid, and the negative control is the pGL3-Basic plasmid. (C) Luciferase activity assay with the mutated IL-20 promoter. ERE half sites on the $I L-20$ promoter were point mutated as described in the Material \& Methods and Figure S1. 293T cells were cotransfected with the ER( $\alpha$ ) plasmid and the indicated plasmid for $24 \mathrm{~h}$, and cell lysates were analyzed for luciferase activity. WT is the pGL3-IL20 plasmid. M-1 is the pGL3-IL20 plasmid with mutation of the -791 and -792 sequences. M-2 is the pGL3-IL20 plasmid with mutation of the -94 and -95 sequences. M-1/M-2 is the pGL3-IL20 plasmid with a double mutation of the $-791 \sim-792$ and $-93 \sim-94$ sequences. (D) The effect of $\operatorname{ER}(\alpha)$ suppression on Ell3 expression. MCF7 cells were transfected with siNS or siER $(\alpha)$ for $48 \mathrm{~h}$, and then Ell3 expression was analyzed by real-time RT-PCR. (E) Left panel: Schematic diagram of the Ell3 promoter. The regions containing ER( $\alpha$ ) consensus binding sequences (EREs) are indicated as R1 to R3 (R1, chr 43,777,200 43,777,301; R2, chr 43,777,402 43,777,551; and R3, chr 43,777,886 43,778,042). Right panel: Chromatin from MCF7 cells transfected with siNS or siEll3 was immunoprecipitated (ChIP) with antibodies against IgG, ER( $\alpha)$ and H3Ac. The PCR results for the R1 region of the Ell promoter are presented. Abbreviation: C, control MCF7 cells; OE, Ell3-overexpressing cells; siNS, non-specific siRNA; siER, siRNA targeting ER( $\alpha$ ); siEll3, siRNA targeting El13. The error bars represent the standard errors from three independent experiments, which were each performed using triplicate samples. $* P<0.05$ (Student's $t$-test). 
in MDA-MB-231 cells is accessible to transcription factors. In other words, the lack of transcription factors is the one of main reasons for the low $I L-20$ expression in MDA-MB-231 cells. However, $I L-20$ expression was not significantly enhanced by estrogen treatment in $\mathrm{ER}(\alpha)$-transfected MDA-MB-231 cells, in contrast to MCF7 cells. It has been previously reported that the transfection of all three transcription factors, including $\operatorname{ER}(\alpha)$, GATA3 and FOXA1, is necessary to restore the estrogen-responsive growth of ER(-) MDA-MB-231 cells [12]. It can be predicted that formation of a transcriptional complex consisting of at least Ell3 and GATA3 is required to restore the estrogen responsiveness of $I L-20$ expression in MDA-MB-231 cells.

In summary, our findings have shown that $I L-20$ expression in breast cancer is regulated by a transcriptional complex composed of transcription factors, including $\operatorname{ER}(\alpha)$, GATA3, and FOXA1, as well as a transcriptional elongation factor, Ell3 (Figure 5). Recent evidence indicates that $I L-20$ is a therapeutic target in various cancers, including breast cancer, and that an anti- $I L-20$ monoclonal antibody has therapeutic potential for alleviating inflammation and osteolysis associated with tumor progression $[9,13,15,16]$. Therefore, we expect that the results of our study will facilitate the development of a new therapeutic strategy for targeting $I L-20$ expression in various diseases, including cancer.

\section{MATERIALS AND METHODS}

\section{Cell culture}

El13-overexpressing (E113 OE) and control MCF7 cells were cultured in DMEM containing 10\% fetal bovine serum and $1 \%$ penicillin/streptomycin. The Ell3 OE cell line was constructed as described previously [6].
A

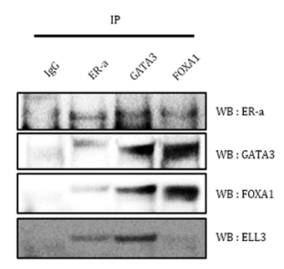

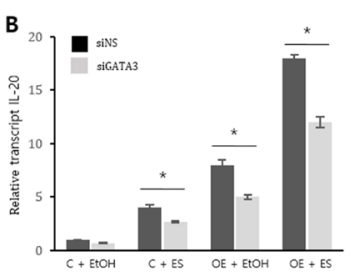

C

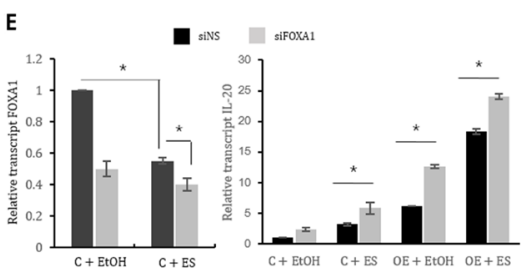

D
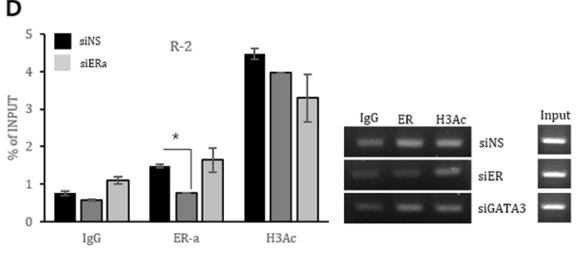

$\mathbf{F}$
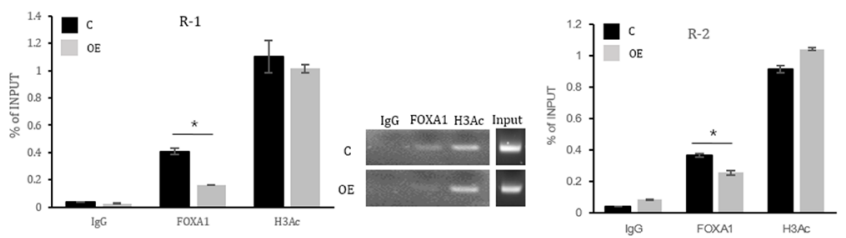

G

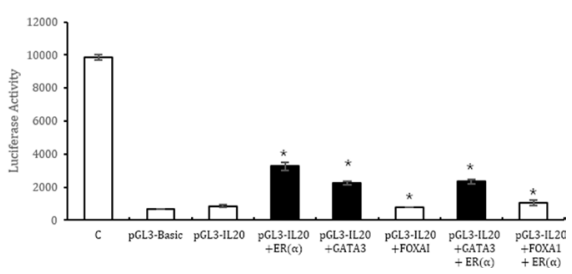

Figure 4: $\operatorname{ER}(\alpha)$, GATA3 and FOXA1 collectively regulate $\boldsymbol{I L}-20$ expression. (A) Co-immunoprecipitation of ER( $\alpha$ ), GATA3, FOXA1 and El13. MCF7 cell lysates were precipitated with anti-ER( $\alpha)$, anti-GATA3 and anti-FOXA1-conjugated agarose and blotted with the indicated antibodies. (B) The effect of GATA3 suppression on $I L-20$ expression in control and Ell3 OE cells in the presence or absence of estrogen. Control and El13 OE cells were transfected with siNS or siGATA3 for 24 h before estrogen treatment. At 24 $\mathrm{h}$ after estrogen treatment, $I L-20$ expression was analyzed by real-time RT-PCR. (C) Chromatin from control and Ell3 OE cells was immunoprecipitated (ChIP) with antibodies against IgG, GATA3 and H3Ac. The PCR results for R1 and R2 of the $I L-20$ promoter are presented. (D) Chromatin from MCF7 cells transfected with siNS, siER $(\alpha)$, and siGATA3 was immunoprecipitated (ChIP) with antibodies against IgG, ER $(\alpha)$ and H3Ac. The PCR results for R2 in the $I L-20$ promoter are presented. (E) The effect of suppression of FOXA1 on $I L-20$ expression in control and Ell3 OE cells. Control and Ell3 OE cells were transfected with siNS or siFOXA1 at $24 \mathrm{~h}$ before estrogen treatment. At $24 \mathrm{~h}$ after estrogen treatment, $I L-20$ expression was analyzed by real-time RT-PCR. (F) Chromatin from control and Ell3 OE cells was immunoprecipitated (ChIP) with antibodies against IgG, FOXA1 and H3Ac. The PCR results for R1 and R2 in the $I L-20$ promoter are presented. (G) Luciferase activity assays of the $I L-20$ promoter in the presence of ER( $\alpha$ ), GATA3 and FOXA1. 293T cells were transfected with the indicated plasmid for $24 \mathrm{~h}$, and cell lysates were analyzed for luciferase activity. The positive control was the pGL3control plasmid, and the negative control was the pGL3-Basic plasmid. Abbreviation: IP, immunoprecipitation; WB, western blot: siNS, non-specific siRNA; siGATA3, siRNA targeting GATA3; siER, siRNA targeting ER( $\alpha$ ); siFOXA1, siRNA targeting FOXA1; C, control MCF7 cells; OE, Ell3-overexpressing cells; H3Ac, acetyl-histone H3. The error bars represent the standard errors from three independent experiments, which were each performed using triplicate samples. ${ }^{*} P<0.05$ (Student's $t$-test). 


\section{Antibodies and immunoblot}

The antibodies used in this study included antiER $(\alpha)$ (Cell Signaling, \#8644), anti-Ell3 (Santa Cruz, Sc242614), anti-ß-actin (Santa Cruz, Sc-47778), anti-GATA3 (Cell Signaling, \#5852), and anti-FOXA1 (Cell Signaling, \#58613). For immunoblot analysis, cells were lysed in tissue lysis buffer (20 mM Tris base, $\mathrm{pH} 7.4,137 \mathrm{mM} \mathrm{NaCl}$, 2 mM EDTA, 1\% Triton X-100, 25 mM $\beta$-glycerophosphate, $2 \mathrm{mM}$ sodium pyrophosphate, $10 \%$ glycerol, $1 \mathrm{mM}$ sodium orthovanadate, $1 \mathrm{mM}$ benzamidine, and $1 \mathrm{mM}$ phenylmethylsulfonyl fluoride). Total cell extracts were resolved by sodium dodecyl sulfate-polyacrylamide gel electrophoresis (SDS-PAGE), transferred to Immobilon-P membranes (Millipore, Bedford, USA), and blotted with antibodies. Immunoreactivity was detected by enhanced chemiluminescence (ECL; Bio-Rad, CA, USA).

\section{Quantification of IL-20 in culture medium}

A human $I L-20$ immunoassay kit was used for $I L-20$ quantification (DL200, R\&D Systems). The optical density of each well was determined using a microplate reader at $450 \mathrm{~nm}$.

\section{Transfection with siRNA}

MCF7 cells were transfected with siRNA using siGENOME (El13, M-014601-01-0005; ER( $\alpha$ ), L-003401-00-0010; GATA3, L-003781-00-0010; and
FOXA1,L-010319-00-0010), which was provided by Dharmacon (distributed by ThermoScientific/AbGen, Epsom, UK). Cells were transfected with either target siRNA or non-specific siRNA using Lipofectamine 2000 (Invitrogen) in OPTI-MEM (Invitrogen) according to the manufacturer's instructions.

\section{Real-time reverse transcription PCR (Real-time RT-PCR)}

RNA was isolated using TRI-reagent (SigmaAldrich, St. Louis, MO, USA). Total RNA (1 $\mu \mathrm{g})$ was reverse transcribed using a 1st Strand cDNA Synthesis system (LeGene, San Diego, CA, USA) according to the manufacturer's protocol. Real-time PCR was performed in triplicate using the primers listed in Supplementary Table 1, with TOPreal qPCR 2X PreMIX (Enzynomics, Korea) and a CFX96 Real-time System (Bio-Rad Laboratories, Richmond, VA, USA). Expression levels were normalized to that of glyceraldehyde 3-phosphate dehydrogenase (GAPDH).

\section{Immunoprecipitation}

Cells were washed with phosphate-buffered saline (PBS) and harvested in lysis buffer. Cell lysates were cleared by centrifugation at $12,000 \mathrm{rpm}$ for $15 \mathrm{~min}$ at $4^{\circ} \mathrm{C}$. For immunoprecipitation, the lysates were incubated with $4 \mu \mathrm{g}$ of antibody for $16 \mathrm{~h}$ at $4^{\circ} \mathrm{C}$, followed by incubation with $30 \mu \mathrm{l}$ of protein $\mathrm{G}$ beads for $1 \mathrm{~h}$ at $4^{\circ} \mathrm{C}$. The beads
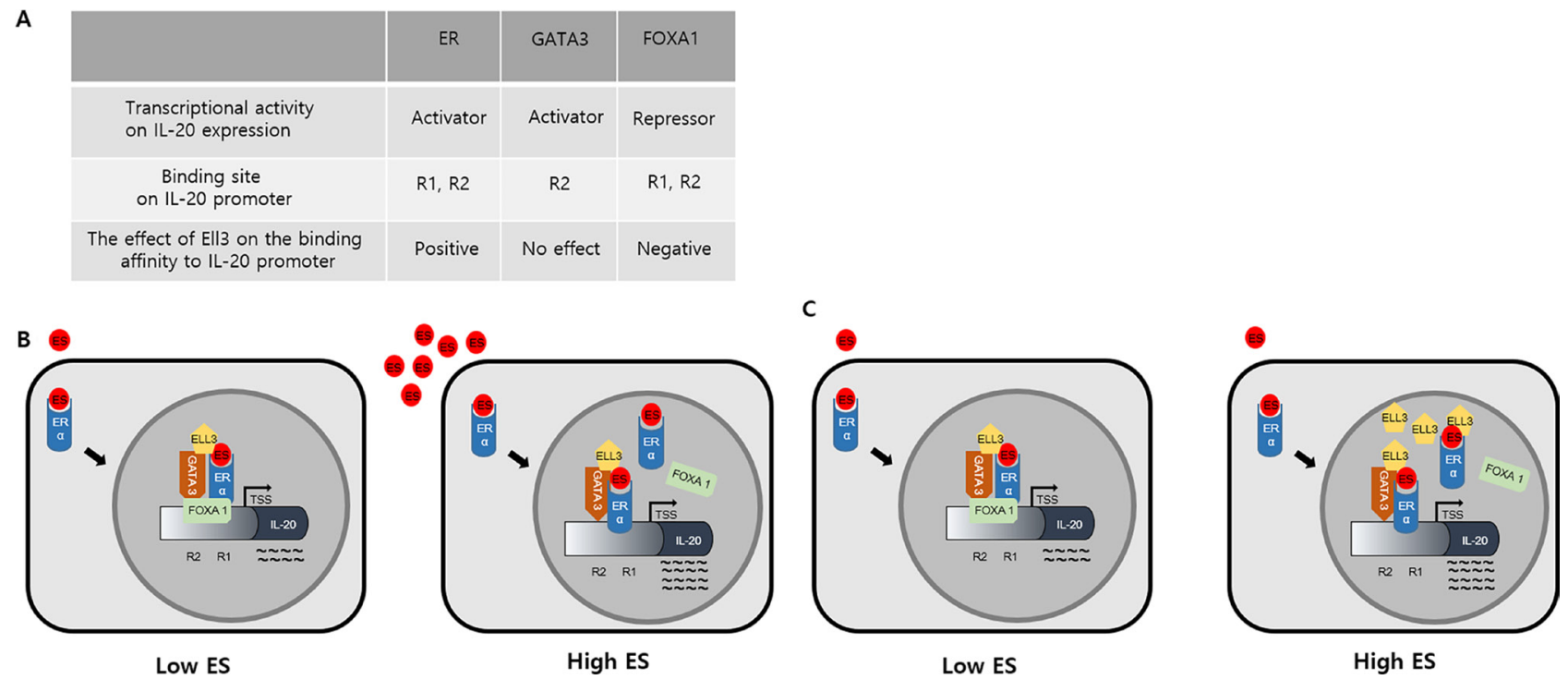

Figure 5: Proposed model of the effects of ER( $\alpha)$, GATA3, FOXA1 and Ell3 activities on $I L-20$ expression in cancer cells. (A) Summary of the effects of the transcriptional activities of ER( $\alpha$ ), GATA3, FOXA1 and Ell3 on $I L-20$ expression in MCF7 cells. (B) Effects of the estrogen-dependent transcriptional activities of ER $(\alpha)$, GATA3 and FOXA1 on $I L-20$ expression. ER $(\alpha)$ and GATA3 are transcriptional activators, and FOXA1 is a transcriptional repressor of $I L-20$ expression at low ES concentrations. At high ES concentrations, the binding affinity of $\operatorname{ER}(\alpha)$ to the EREs is enhanced to prevent the binding of FOXA1, resulting in increased transcription of $I L-20$. (C) Effects of the Ell3-dependent transcriptional activities of ER $(\alpha)$, GATA 3 and FOXA 1 on $I L-20$ expression. $\operatorname{ER}(\alpha)$ and GATA 3 are transcriptional activators, and FOXA1 is a transcriptional repressor of $I L-20$ expression at a normal cellular concentration of Ell3. Ell3 overexpression enhances the binding affinity of $\mathrm{ER}(\alpha)$ to the ERE to exclude FOXA1, resulting in increased transcription of $I L-20$. 
were washed once in lysis buffer. Then, the samples were boiled in SDS-PAGE sample buffer and analyzed by western blotting.

\section{Chromatin immunoprecipitation}

A $1 \%$ formaldehyde solution was added to the cell culture medium for $10 \mathrm{~min}$ at $37^{\circ} \mathrm{C}$. Cells were washed three times with cold PBS and then resuspended in lysis buffer (1\% SDS, $10 \mathrm{mM}$ EDTA, and $50 \mathrm{mM}$ Tris- $\mathrm{HCl}, \mathrm{pH}$ 8.1) with $1 \mathrm{mM}$ phenylmethylsulfonyl fluoride (PMSF). After brief sonication, the lysates were cleared by centrifugation and diluted 5-fold with dilution buffer $(0.01 \%$ SDS, $1 \%$ Triton X-100, $1.2 \mathrm{mM}$ EDTA, $16.7 \mathrm{mM}$ Tris- $\mathrm{HCl}, \mathrm{pH} 8.1$, and $167 \mathrm{mM} \mathrm{NaCl}$ ) containing PMSF. Then, the lysates were incubated with an anti$\mathrm{ER}(\alpha)$ antibody overnight at $4^{\circ} \mathrm{C}$. Immune complexes were precipitated with Protein A/G Plus Agarose. The precipitates were sequentially washed with low-salt wash buffer $(0.1 \%$ SDS, $1 \%$ Triton X-100, 2 mM EDTA, 20 mM Tris-HCl, $\mathrm{pH}$ 8.1 , and $150 \mathrm{mM} \mathrm{NaCl})$, high-salt wash buffer $(0.1 \% \mathrm{SDS}$, $1 \%$ Triton X-100, 2 mM EDTA, 20 mM Tris-HCl, pH 8.1, and $500 \mathrm{mM} \mathrm{NaCl})$ and $\mathrm{LiCl}$ wash buffer $(0.25 \mathrm{M} \mathrm{LiCl}, 1 \%$ NP-40, $1 \%$ deoxycholate, $1 \mathrm{mM}$ EDTA, and $10 \mathrm{mM}$ Tris$\mathrm{HCl}, \mathrm{pH}$ 8.1). After the final wash, elution buffer (1\% SDS and $0.1 \mathrm{M} \mathrm{NaHCO}_{3}$ ) was added, followed by incubation at room temperature for $15 \mathrm{~min}$ with rotation. Then, the formaldehyde crosslinking was reversed by adding $0.3 \mathrm{M}$ $\mathrm{NaCl}$ and heating at $65^{\circ} \mathrm{C}$ for $4 \mathrm{~h}$. Next, proteinase $\mathrm{K}$ was added, followed by incubation at $45^{\circ} \mathrm{C}$ for $1 \mathrm{~h}$. Then, DNA was recovered by phenol-chloroform extraction and ethanol precipitation. The resulting pellets were resuspended in TE buffer and subjected to PCR using primers for the promoter of $I L-20$ or Ell3. The PCR products were separated by agarose gel electrophoresis.

\section{Luciferase reporter constructs and assay}

The $5^{\prime}$ upstream regulatory region of the $I L-20$ gene $(-808 \sim+1)$ was PCR amplified and cloned into the pGL3 luciferase reporter vector (Promega, Madison, WI, USA). Two potential ER $(\alpha)$ binding sites (ERE: estrogen response element) (-791 -792 and -93 -94) on the $I L-20$ promoter were mutated as described in Supplementary Figure 1 and cloned into the pGL3 luciferase reporter vector. Then, $6 \times 10^{4}$ cells of $293 \mathrm{~T}$ were seeded in each well of a 24-well tissue plate and cotransfected with pGL3 reporter plasmid, pGL3-Basic plasmid, pGL3control plasmid and SV40ß-galactosidase vector for normalizing transfection efficiency per well according to the manufacturer's instructions. Firefly luciferase activity was measured in cell lysates $24 \mathrm{~h}$ after transfection using the Luciferase Assay System (Promega). Experiments were repeated at least three times with three replicates per sample for each experiment. The results are normalized against $\beta$-galactosidase activity.

\section{Statistical analysis}

Each experiment was performed at least three times. Statistical significance of data analysis between two groups was determined using Student's $t$-test, and a $P$ value of $<0.05$ was considered significant. All statistical analyses were performed using the SAS statistical package, v.9.13 (SAS, Cary, NC, USA).

\section{ACKNOWLEDGMENTS AND FUNDING}

This work was funded by the Ministry of Education, Science, and Technology (2015R1A2A2A01003498).

\section{CONFLICTS OF INTEREST}

The authors have no potential conflicts of interest in relation to this article.

\section{REFERENCES}

1. Green KA, Carroll JS. Oestrogen-receptor-mediated transcription and the influence of co-factors and chromatin state. Nat Rev Cancer. 2007; 7:713-722.

2. Mann M, Krishnan S, Vadlamudi RK. Emerging significance of estrogen cancer coregulator signaling in breast cancer. Minerva Ginecol. 2012; 64:75-88.

3. Miller T, Williams K, Johnstone RW, Shilatifard A. Identification, cloning, expression, and biochemical characterization of the testis-specific RNA polymerase II elongation factor ELL3. J Biol Chem. 2000; 275: 32052-32056.

4. Lin C, Garruss AS, Luo Z, Guo F, Shilatifard A. The RNA Pol II elongation factor Ell3 marks enhancers in ES cells and primes future gene activation. Cell. 2013; 152:144-156.

5. Ahn HJ, Cha Y, Moon SH, Jung JE, Park KS. Ell3 enhances differentiation of mouse embryonic stem cells by regulating epithelial-mesenchymal transition and apoptosis. PLoS One. 2012; 7:e40293.

6. Ahn HJ, Kim KS, Shin KW, Lim KH, Kim JO, Lee JY, Kim J, Park JH, Yang KM, Baek KH, Ko JJ, Park KS. Ell3 stabilizes p53 following CDDP treatment via its effects on ubiquitin-dependent and-independent proteasomal degradation pathways in breast cancer cells. Oncotarget. 2015; 6:44523-44537. doi: 10.18632/oncotarget.5972.

7. Wegenka UM. IL-20: biological functions mediated through two types of receptor complexes. Cytokine Growth Factor Rev. 2010; 21:353-363.

8. Kayani WT, Bandeali SJ, Lee VV, Elayda M, Khan A, Nambi V, Jneid H, Alam M, Wilson JM, Huang HD, Birnbaum Y, Ballantyne CM, Virani SS. Association between statins and infections after coronary artery bypass grafting. Int J Cardiol. 2013; 168:117-120.

9. Hsu YH, Wei CC, Shieh DB, Chan CH, Chang MS. AntiIL-20 monoclonal antibody alleviates inflammation in oral 
cancer and suppresses tumor growth. Mol Cancer Res. 2012; 10:1430-1439.

10. Otkjaer K, Kragballe K, Johansen C, Funding AT, Just H, Jensen UB, Sorensen LG, Norby PL, Clausen JT, Iversen L. IL-20 gene expression is induced by IL-1beta through mitogen-activated protein kinase and NF-kappaB-dependent mechanisms. J Invest Dermatol. 2007; 127:1326-1336.

11. Lacroix M, Leclercq G. About GATA3, HNF3A, and XBP1, three genes co-expressed with the oestrogen receptor-alpha gene (ESR1) in breast cancer. Mol Cell Endocrinol. 2004; 219:1-7.

12. Kong SL, Li G, Loh SL, Sung WK, Liu ET. Cellular reprogramming by the conjoint action of ERalpha, FOXA1, and GATA3 to a ligand-inducible growth state. Mol Syst Biol. 2011; 7:526.

13. Hsu YH, Hsing CH, Li CF, Chan CH, Chang MC, Yan JJ, Chang MS. Anti-IL-20 monoclonal antibody suppresses breast cancer progression and bone osteolysis in murine models. J Immunol. 2012; 188:1981-1991.
14. Hisamatsu Y, Tokynaga E, Yamashita N, Akiyoshi S, Okada S, Nakashima Y, Taketani K, Aishima S, Oda Y, Morita M, Maehara Y. Impact of GATA-3 and FOXA1 expression in patients with hormone receptor-positive/HER2 negative breast cancer. Breast Cancer. 2015; 22:520-528.

15. Hsu YH, Chang MS. The therapeutic potential of antiinterleukin-20 monoclonal antibody. Cell Transplant. 2014; 23:631-639.

16. Hsu YH, Wu CY, Hsing CH, Lai WT, Wu LW, Chang MS. Anti-IL-20 monoclonal antibody suppresses prostate cancer growth and bone osteolysis in murine models. PLoS One. 2015; 10:e0139871. 